\title{
Optimizing glycemic control in type 2 diabetic patients through the use of a low-carbohydrate, high-fat, ketogenic diet: a review of two patients in primary care
}

This article was published in the following Dove Medical Press journal: Diabetes, Metabolic Syndrome and Obesity:Targets and Therapy

\author{
Stefan Rallis \\ Dr. Rallis Wellness Group, Barrie, ON, \\ Canada
}

Video abstract

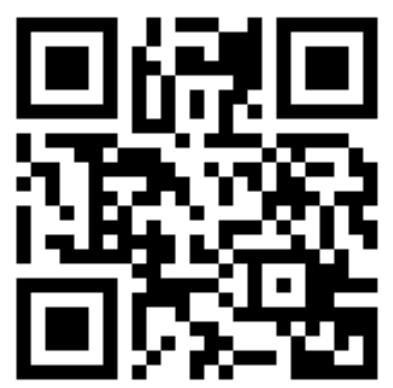

Point your SmartPhone at the code above. If you have a QR code reader the video abstract will appear. Or use: http://youtu.be/NKKMMMES_pl
Correspondence: Stefan Rallis

Dr. Rallis Wellness Group, 470 Big Bay

Point Road, Barrie, ON L4N 3Z4, Canada

Tel +l 7057333484

Fax +l 7057333997

Email info@wellnessdoctor.ca

\begin{abstract}
Established guidelines continue to promote carbohydrate-rich ( $>130 \mathrm{~g} /$ day) diets in the primary-care management of type 2 diabetic (DM2) patients. A growing body of evidence suggests that a low-carbohydrate, high-fat, ketogenic diet $(\mathrm{KD})$ may be a more effective nutritional strategy for improving glycemic control. Two diabetic patients, a 65 -year-old female and a 52 -year-old male, were placed on KDs consisting of $70 \%$ fat, $20 \%-25 \%$ protein, and $5 \%-10 \%$ carbohydrates and monitored for 12 weeks. The 65 -year-old female demonstrated a $2.4 \%$ reduction in HBA1C over 12 weeks while reducing her diabetic medication by $75 \%$. The 52 -year-old male demonstrated a $2.5 \%$ reduction in HBA1C while eliminating all diabetic medications. These cases demonstrate the efficacy of KDs in terms of improving glycemic control in DM2 patients and lend support to the increased use of KDs in this population cohort.
\end{abstract}

Keywords: case series, diabetes, HBA1C, improved glycemic control

\section{Introduction}

According to the 2015 statistics from Diabetes Canada, 9.3\% of Canadians have diabetes, 90\% of which are type 2 diabetic (DM2) patients. By 2025, the number of Canadians with diabetes is expected to increase by $44 \%$. A staggering $22.1 \%$ of Canadians have prediabetes. ${ }^{1}$ Meta-analyses demonstrate an increased risk of multiple diabetic comorbidities including increased heart and cardiovascular disease, a higher likelihood of neuropathies and retinopathies, increased kidney and liver disease, increased sexual dysfunction, and the higher risk of developing dementia and certain cancers. Diabetes is also the leading cause of blindness, end-stage kidney disease, and amputations in Canada. ${ }^{2}$

Maintaining glycemic control is central to the effective management of diabetes. Elevation in HBA1C is directly correlated with increased diabetic complications including risk of both microvascular and cardiovascular sequelae. Present guidelines recommend a HBA $1 \mathrm{C}$ target of $\leq 7.0 \%$ for most diabetic patients. ${ }^{3}$ The progressive loss of insulin sensitivity and the increase in glucose resistance associated with chronic diabetes result very characteristically in a progressive increase in both $\mathrm{HBA} 1 \mathrm{C}$ and the number of medications required to manage this disease. ${ }^{4}$ Consequently, drug therapy alone is generally inadequate in stemming the long-term implications and metabolic deteriorations associated with this disease. Multifactorial strategies are recommended including diet and lifestyle modifications. ${ }^{5}$ 
In terms of nutritional therapies, Diabetes Canada recommends DM2 patients limit sugar and fat intake and consume "no less than $130 \mathrm{~g}$ /day" of carbohydrates per day, or $45 \%-60 \%$ of daily dietary intake. Fifteen to twenty percent of calories are further recommended as protein and 20\%-35\% of daily calories be consumed as fat, with $<9 \%$ of macronutrient intake derived from saturated fat. The goal of these guidelines is to prevent blood sugar spikes and weight gain, while providing the body with necessary energy from starchderived glucose ${ }^{6}$ Consistent with established guidelines, our clinical experience shows that patients referred to diabetic clinics in the province of Ontario are usually instructed to follow lower fat, carbohydrate-dominant diets.

There is a growing body of evidence that suggests a highfat, low-carbohydrate, ketogenic diet (KD) may be a more effective diet in modifying diabetes clinical targets. A KD uses dietary macronutrient content modification to promote a shift from a carbohydrate to a lipid dominant metabolism. In order to achieve a ketogenic state, carbohydrate intake must be restricted to about $10 \%$ of total dietary intake. Protein and fat should make up $\sim 20 \%$ and $\sim 70 \%$ of the diet, respectively. ${ }^{7}$ Under these conditions, the body begins to upregulate lipolytic enzymes and bypass the dependence on glucose for energy. ${ }^{8}$

Given that the primary pathology in DM2 patients is an elevation in serum glucose, implementing a novel, nonglucose-requiring fuel system, such as that employed in a $\mathrm{KD}$, may offer a compelling alternative in the treatment of this disease. Two diabetic patients were placed on a KD at our integrative primary-care office, located in Barrie, Ontario and monitored closely for 3 months. This case series presents the clinical outcomes related to diabetes and comorbidities as well as patient acceptability and feasibility in clinical practice. Written, informed consent was obtained from both patients with respect to their participation in this case series, including release of medical information for purposes of research publication.

\section{Case presentation Patient I, 65-year-old female}

A 65-year-old female consulted our office for naturopathic primary-care support for a myriad of conditions, which included diabetes with weight gain, chronic fatigue, depression with emotional lability, frequent colds, and recurrent urinary tract infections. The latter was attributed to a medullary sponge kidney as was her history of kidney stones and hypertension. The patient also suffered with long-standing acid reflux and was prone to irritable bowel with diarrhea. She had also suffered with multiple abscesses in the past as well as poor generalized wound healing. A history of fibroadenomas was also noted. The patient recollected, "never being well", even as a child. She described her diet as a child as "deficient" and consisted mostly of canned beans and bread, which she attributed to her poor socioeconomic status as a child.

Pharmacological management of her diabetic condition included the use of metformin/sitagliptin (1,000 mg/50 mg, taken twice per day) and gliclazide (30 mg), also taken twice per day.

Additional medications included ramipril ( $5 \mathrm{mg} /$ day), ranitidine (150 mg, twice per day), low-dose aspirin (81 mg/ day), hydrochlorothiazide (25 mg/day), allopurinol (100 mg/ day), citalopram (40 mg/day), and mirabegron (50 mg/day).

Physical examination revealed a $1.69 \mathrm{~m}$ (66.5 inch), 88.5 $\mathrm{kg}(195.0 \mathrm{lb})$ female. Body mass index was calculated at 31.0 (Obese Class I) (32). Central waist measurement was $112 \mathrm{~cm}$, while her hips measured $118 \mathrm{~cm}$. Blood pressure was 114/64 $\mathrm{mmHg}$, measured at the left brachial artery. Bioimpedance analysis revealed a lean body mass of $49.9 \mathrm{~kg}$ (111.0 lbs) and a fat mass of $38.0 \mathrm{~kg}(84.0 \mathrm{lbs})$.

Laboratory assessment prior to date of initial consult (June 2017) revealed a HBA1C of $7.8 \%$ and a random glucose of $6.5 \mathrm{mmol} / \mathrm{L}$. Total cholesterol (TC) was 4.68 $\mathrm{mmol} / \mathrm{L}$, triglycerides (TG) were $2.63 \mathrm{mmol} / \mathrm{L}$, high-density lipoproteins (HDL) was $1.04 \mathrm{mmol} / \mathrm{L}$, low-density lipoproteins (LDL) was $2.44 \mathrm{mmol} / \mathrm{L}$, and TC:HDL was 4.5 . Alanine aminotransferase was $55 \mathrm{U} / \mathrm{L}$, while creatinine was $79 \mu \mathrm{mol} / \mathrm{L}$.

\section{Patient 2, 52-year-old male}

A 52-year-old married male expressed interest in seeking a second opinion on his progressively worsening diabetic issue, which included increases in his medication (metformin/sitagliptin $500 \mathrm{mg} / 50 \mathrm{mg}$, taken twice daily), his body weight, and HBA1C. The patient had received chiropractic care at our clinic previously for the occasional musculoskeletal concern. Beyond the aforementioned diabetic medications, the patient was also taking a rabeprazole for acid reflux (40 $\mathrm{mg}$ /day), rosuvastatin for hyperlipidemia (10 mg/day), and perindopril-indapamide for hypertension (4 mg/1.25 mg, twice per day). He thought that some of his disease progression may be attributed to a more sedentary work environment over the last few years.

Physical examination revealed a $1.69 \mathrm{~m}$ (66.5 inch), 96.2 $\mathrm{kg}(212.0 \mathrm{lbs})$ male. Body mass index was calculated at 33.2 (Obese Class I) (32). Central waist measurement was 108.5 $\mathrm{cm}$, while his hips measured $107 \mathrm{~cm}$. Blood pressure was 
$126 / 80 \mathrm{mmHg}$, measured at the left brachial artery. Bioimpedance analysis revealed a lean body mass of $71.8 \mathrm{~kg}$ (158.2 lbs) and a fat mass of $24.4 \mathrm{~kg}(53.8 \mathrm{lbs})$.

Laboratory assessment prior to onset of dietary changes revealed a HBA1C of $8.0 \%$ and a fasting glucose of 8.4 $\mathrm{mmol} / \mathrm{L}$. TC was $3.44 \mathrm{mmol} / \mathrm{L}$, TG were $1.25 \mathrm{mmol} / \mathrm{L}$, HDL was $0.93 \mathrm{mmol} / \mathrm{L}$, LDL was $1.94 \mathrm{mmol} / \mathrm{L}$, and TC:HDL was 3.7. High-sensitivity C-reactive protein (hs-CRP) was calculated at $3.65 \mathrm{mg} / \mathrm{L}$

\section{Therapeutic approach}

Both patients were instructed to follow a diet that contained $70 \%$ fat, $20 \%$ protein, and $10 \%$ carbohydrates. They were further instructed to try and maintain a caloric load between 1,200 and 2,000 calories; however, the emphasis was placed on the macronutrient ratios of the diet - keeping fat consumption high and restricting carbohydrates. They were also asked to keep detailed food journals for purposes of objective assessment. Compliance was determined through the review of these dietary journals with respect to macronutrient ratios, caloric intake, and the presence of ketone bodies through urinalysis. All details were tracked and recorded in the patient file. Their first follow-up was scheduled 1 week after starting the program in order to address any patient concerns. Three additional follow-ups were scheduled at weeks 4,8 , and after the completion of the program (week 12). Any additional health issues or concerns were further addressed in these primary-care visits. Labs were assessed at 6- and 12-week intervals.

\section{Follow-up and outcomes \\ Patient I, 65-year-old female}

The patient was able to establish dietary compliance after the first consult, in which the diet was introduced, and she was given a short, written dietary outline.

At the patient's first follow-up, she mentioned noticing weight loss and dropping glucose levels during self-monitoring. Review of the patient's dietary journal revealed a high level of compliance, determined through the calculation of both daily macronutrients and calories. She was consistently within $2 \%-3 \%$ of all respective macronutrient ratios, within caloric range, and urinalysis consistently revealed presence of ketone bodies. In terms of adverse reporting, the patient felt some intermittent nausea and increased diaphoresis within several days of implementing the diet. Due to reducing blood sugar levels, the patient was recommended to stop gliclazide and to add ginger to her tea, whenever she felt nauseous. Overall, she felt that the diet was very easy to follow and also felt optimistic at the rapid results she was experiencing. At the 6-week mark, labs to assess progress were performed and shared with her nurse practitioner. Of note was a very dramatic reduction in $\mathrm{HBA} 1 \mathrm{C}(2.2 \%)$ as well as a 0.78 $\mathrm{mmol} / \mathrm{L}$ reduction in triglycerides. Her second diabetes combination medication metformin/sitagliptin 1,000 mg/50 $\mathrm{mg}$, which was taken two times per day, was reduced at this point to metformin/sitagliptin $500 \mathrm{mg} / 25 \mathrm{mg}$, once per day. The patient was extremely pleased with progress and reported that her sleep was also improved.

At the 12-week mark, a full set of both labs and biometrics were performed. A significant improvement was noted in glycemic control (2.4\% reduction in HBA1C), concurrent with a reduction in her diabetic medications (discontinued gliclazide, $75 \%$ reduction in metformin/sitagliptin). Ramipril was also reduced to $2.5 \mathrm{mg} /$ day (50\% reduction). Positive biometric change was also noted including a $15.3 \mathrm{~kg}$ loss in total body weight, a reduction in central waist measurement $(16 \mathrm{~cm}$ ), as well as improvements to her lipid panel (see Tables 1 and 2).

\section{Patient 2, 52-year-old male}

At the patient's first follow-up, a review of his dietary journal demonstrated high compliance, based upon adherence to macronutrient range and the presence of ketone bodies during urinalysis and secondarily by maintaining moderate caloric restriction. A loss of $2.8 \mathrm{~kg}$ was also noted at this follow-up. Laboratory and biometric assessments were conducted at weeks 6 and 12. At the 6 -week mark, the patient demonstrated significant improvement in glycemic control (1.8\% reduction in HBA1C) as well as improvement to every facet of his lipid profile, liver enzymes, and cardiac risk markers fibrinogen and hs-CRP (see Table 3). The patient had further discontinued his diabetes medication (metformin/sitagliptin 1,000 $\mathrm{mg} / 50 \mathrm{mg}$ ) after 1 week of establishing dietary compliance.

At the 12-week mark, a biometric reevaluation was conducted in concert with another laboratory assessment.

Table I Biometric assessment of patient I (65-year-old female)

\begin{tabular}{|l|l|l|}
\hline Biometric test & Pre-diet & Post-diet \\
\hline Body weight & $88.5 \mathrm{~kg} / \mathrm{I} 95.0 \mathrm{lbs}$ & $73.2 \mathrm{~kg} / \mathrm{I} 6 \mathrm{I} .4 \mathrm{lbs}$ \\
\hline Lean body mass & $49.9 \mathrm{~kg} / \mathrm{III} .0 \mathrm{lbs}$ & $46.1 \mathrm{~kg} / \mathrm{I0I} .4 \mathrm{lbs}$ \\
\hline Fat mass & $38.1 / 84.0 \mathrm{lbs}$ & $46.0 \mathrm{~kg} / 60.0 \mathrm{lbs}$ \\
\hline Blood pressure & $114 / 64 \mathrm{mmHg}$ & $114 / 7 \mathrm{I} \mathrm{mmHg}$ \\
\hline Waist measurement & $112 \mathrm{~cm}$ & $96 \mathrm{~cm}$ \\
\hline Hip measurement & $118 \mathrm{~cm}$ & $103 \mathrm{~cm}$ \\
\hline W:H & 0.95 & 0.93 \\
\hline
\end{tabular}

Abbreviation: $\mathrm{W}: \mathrm{H}$, waist to hip ratio. 
Table 2 Laboratory assessments of patient I (65-year-old female)

\begin{tabular}{|l|l|l|l|}
\hline Laboratory assessment & Pre-diet & Week 6 & Week I2 \\
\hline HBAIC (\%) & $7.8 \%$ & $5.6 \%$ & $5.4 \%$ \\
\hline Glucose random/fasting & $6.5 \mathrm{mmol} / \mathrm{L}$ (random) & $7.5 \mathrm{mmol} / \mathrm{L}$ (fasting) & $5.8 \mathrm{mmol} / \mathrm{L}$ (fasting) \\
\hline Triglycerides & $2.63 \mathrm{mmol} / \mathrm{L}$ & $1.85 \mathrm{mmol} / \mathrm{L}$ & $\mathrm{I} .27 \mathrm{mmol} / \mathrm{L}$ \\
\hline Total cholesterol (TC) & $4.68 \mathrm{mmol} / \mathrm{L}$ & $4.64 \mathrm{mmol} / \mathrm{L}$ & $4.5 \mathrm{mmol} / \mathrm{L}$ \\
\hline High-density lipoproteins (HDL) & $1.04 \mathrm{mmol} / \mathrm{L}$ & $1.02 \mathrm{mmol} / \mathrm{L}$ & $\mathrm{I}$ \\
\hline Low-density lipoproteins & $2.44 \mathrm{mmol} / \mathrm{L}$ & $2.78 \mathrm{mmol} / \mathrm{L}$ & $2.75 \mathrm{mmol} / \mathrm{L}$ \\
\hline TC:HDL & 4.5 & 4.5 & 3.8 \\
\hline Alanine aminotransferase & $55 \mathrm{U} / \mathrm{L}$ & $19 \mathrm{U} / \mathrm{L}$ & $\mathrm{II} \mathrm{U/L}$ \\
\hline Creatinine & $79 \mu \mathrm{mol} / \mathrm{L}$ & $79 \mu \mathrm{mol} / \mathrm{L}$ & $74 \mu \mathrm{mol} / \mathrm{L}$ \\
\hline
\end{tabular}

HBA1C (glycemic control) improved to normal levels (5.5\%) even without medication. Biometric changes included a $12.9 \mathrm{~kg}$ loss in total body weight, an $11.5 \mathrm{~cm}$ reduction in central waist measurement, and a very mild reduction in blood pressure (patient was still medicated). Liver enzymes were not tested at the 12-week mark. The improvements noted in the patients' lipid panel and hs-CRP at week 6 were relatively maintained at week 12 (see Tables 3 and 4). The patient was incredibly pleased with progress and felt that he could maintain the dietary modifications if he was able to include the occasional meal that included a higher amount of carbohydrates. The patient's acid reflux also resolved on this diet, and he was able to eliminate the use of rabeprazole.

\section{Discussion}

These cases illustrate the increasingly divergent nature of diabetes treatment in primary care. On the one hand, there is a growing body of evidence that suggests a high-fat, low-carbohydrate KD may be the most effective dietary intervention in the treatment of DM2., ${ }^{9,10}$ On the other hand, established guidelines (including those recently released by Diabetes Canada [2018]) continue to recommend the idea of a carbohydrate-rich diet in the nutritional management of the diabetic patient. It is not surprising therefore that there is a very characteristic worsening of the metabolic disease and need for further medication in most patients. Prior to implementing the $\mathrm{KD}$, both patients in this case series were good examples of this characteristic phenomenon. Future follow-ups were discussed with both patients who agreed that they would be able to continue to follow the tenets of the program as they both felt their health and quality of life had improved immeasurably secondary to the prescribed lifestyle modifications.

Long-term sustainability was not assessed beyond 12 weeks, a weakness of this study. Hallberg et al did assess compliance of the KD among diabetic patients using objective serum ketone monitoring and demonstrated that $87 \%$ of their participants were able to maintain a $\mathrm{KD}$ for at least
Table 3 Laboratory assessments of patient 2 (52-year-old male)

\begin{tabular}{|l|l|l|l|}
\hline Laboratory assessment & Pre-diet & Week 6 & Week I2 \\
\hline HBAIC & $8.0 \%$ & $6.2 \%$ & $5.5 \%$ \\
\hline Glucose random/fasting & $\begin{array}{l}8.4 \mathrm{mmol} / \mathrm{L} \\
\text { (fasting) }\end{array}$ & $6.1 \mathrm{mmol} / \mathrm{L}$ & $\begin{array}{l}6.2 \mathrm{mmol} / \mathrm{L} \\
\text { (fasting) }\end{array}$ \\
\hline Triglycerides & $1.25 \mathrm{mmol} / \mathrm{L}$ & $1.12 \mathrm{mmol} / \mathrm{L}$ & $\mathrm{I} .31 \mathrm{mmol} / \mathrm{L}$ \\
\hline Total cholesterol (TC) & $3.44 \mathrm{mmol} / \mathrm{L}$ & $3.10 \mathrm{mmol} / \mathrm{L}$ & $3.76 \mathrm{mmol} / \mathrm{L}$ \\
\hline $\begin{array}{l}\text { High-density lipoproteins } \\
\text { (HDL) }\end{array}$ & $0.93 \mathrm{mmol} / \mathrm{L}$ & $1.03 \mathrm{mmol} / \mathrm{L}$ & $0.99 \mathrm{mmol} / \mathrm{L}$ \\
\hline Low-density lipoproteins & $1.94 \mathrm{mmol} / \mathrm{L}$ & $1.56 \mathrm{mmol} / \mathrm{L}$ & $2.17 \mathrm{mmol} / \mathrm{L}$ \\
\hline TC:HDL & 3.7 & 3.0 & 3.8 \\
\hline Alanine transaminase & $50 \mathrm{U} / \mathrm{L}$ & $34 \mathrm{U} / \mathrm{L}$ & Not assessed \\
\hline Aspartate transaminase & $26 \mathrm{U} / \mathrm{L}$ & $27 \mathrm{U} / \mathrm{L}$ & Not assessed \\
\hline $\begin{array}{l}\text { Gamma- } \\
\text { glutamyltransferase }\end{array}$ & $49 \mathrm{U} / \mathrm{L}$ & $26 \mathrm{U} / \mathrm{L}$ & Not assessed \\
\hline Fibrinogen & $4.02 \mathrm{~g} / \mathrm{L}$ & $3.20 \mathrm{~g} / \mathrm{L}$ & Not assessed \\
\hline $\begin{array}{l}\text { High-sensitivity c-reactive } \\
\text { protein }\end{array}$ & $3.65 \mathrm{mg} / \mathrm{L}$ & $0.96 \mathrm{mg} / \mathrm{L}$ & 1.12 \\
\hline
\end{tabular}

Table 4 Biometric assessments of patient 2 (52-year-old male)

\begin{tabular}{|l|l|l|}
\hline Biometric test & Pre-diet & Post-diet \\
\hline Body weight & $96.2 \mathrm{~kg} / 2 \mathrm{I} 2 \mathrm{lbs}$ & $83.3 \mathrm{~kg} / \mathrm{l} 83.6 \mathrm{lbs}$ \\
\hline Lean body mass & $71.7 \mathrm{~kg} / 158.0 \mathrm{lbs}$ & $66.2 \mathrm{~kg} / 146.0 \mathrm{lbs}$ \\
\hline Fat mass & $24.4 \mathrm{~kg} / 53.8 \mathrm{lbs}$ & $17.1 \mathrm{~kg} / 37.6 \mathrm{lbs}$ \\
\hline Blood pressure & $126 / 80 \mathrm{mmHg}$ & $121 / 78 \mathrm{mmHg}$ \\
\hline Waist measurement & $108.5 \mathrm{~cm}$ & $97 \mathrm{~cm}$ \\
\hline Hip measurement & $107 \mathrm{~cm}$ & $101 \mathrm{~cm}$ \\
\hline W:H & $1.0 \mathrm{I}$ & 0.96 \\
\hline
\end{tabular}

Abbreviation: $\mathrm{W}: \mathrm{H}$, waist to hip ratio.

1 year. ${ }^{11}$ Dietary fats appear to play a role in mood stability, ${ }^{12}$ and endogenously produced ketone bodies (by-product of a KD) naturally suppress appetite ${ }^{13}$ both of which may assist in improving patient satisfaction and compliance with this nutritional methodology. A recent meta-analysis by Sainsbury et al however found that while carbohydrate-restricted diets produced greater reductions in HBA1C at 3 and 6 months, there was no statistically significant difference at 12 or 24 months. ${ }^{14}$ Further, it is difficult to ascertain whether all the 
observed metabolic improvements were due to restricted carbohydrates, high fat, or due partially to caloric restriction. It is also worth acknowledging the inclusion of lower carbohydrate dietary strategies in a recently released joint consensus report by the American Diabetic Association and the European Association for the Study of Diabetes. ${ }^{15}$ If maintaining glycemic control is the central measure of success in the effective management of diabetes, it would stand to reason that further research be committed to studying KDs as a potential first-line therapy.

\section{Conclusion}

These cases dramatically illustrate the magnitude of improved glycemic control possible with high-fat, low-carbohydrate, KDs and in the case of the 52-year-old male patient, a reversal in his condition. The diet was easy to prescribe and implement in a busy primary-care setting and was acceptable to the patients and resulted in improvement to comorbidities in addition to glycemic control. This case series, in conjunction with the previous research on this intervention, provides justification for large-scale randomized controlled trials to further investigate the safety and efficacy of this intervention in the treatment of diabetes. Present nutritional guidelines appear biased towards the promotion of carbohydrate-rich diets. Higher fat, lower carbohydrate diets may be more efficacious in helping treat this disease and in potentially curbing this epidemic. Further research is needed.

\section{Ethical approval}

Institutional's ethical approval was not required to publish the details of these cases.

\section{Acknowledgments}

Special thank you to Kieran Cooley ND, Research Director and to Monique Aucoin ND and Samah Hassan MD (Egypt), MSc, Research Fellows at the Canadian College of Naturopathic Medicine for their assistance and direction. Thank you also to Jane Sagura, student at the Canadian College of Naturopathic Medicine for assistance in helping compile the relevant research for this case series.

\section{Disclosure}

The author reports no conflicts of interest in this work.

\section{References}

1. Diabetes Statistics in Canada (2015). Available from: http://www.diabetes.ca/how-you-can-help/advocate/why-federal-leadership-is-essential/ diabetes-statistics-in-canada. Retrieved March 17, 2018.

2. Public Health Agency of Canada (2015, December 17). Type 2 diabetes. Available from: https://www.canada.ca/en/public-health/services/ diseases/type-2-diabetes.html. Retrieved March 17, 2018.

3. Individualizing Your Patient's A1C Target (2018). Available from: $\mathrm{http} / / /$ guidelines.diabetes.ca/reduce-complications/a1ctarget. Accessed September 14, 2018.

4. Higgins V, Piercy J, Roughley A, et al. Trends in medication use in patients with type 2 diabetes mellitus: a long-term view of real-world treatment between 2000 and 2015. Diabetes Metab Syndr Obes. 2016;9:371-380.

5. Turner RC, Cull CA, Frighi V, Holman RR. Glycemic control with diet, sulfonylurea, metformin, or insulin in patients with type 2 diabetes mellitus: progressive requirement for multiple therapies (UKPDS 49). UK Prospective Diabetes Study (UKPDS) group. JAMA. 1999;281(21):2005.

6. Canadian Diabetes Association Clinical Practice Guidelines Expert Committee, Dworatzek PD, et al. Nutrition therapy. Can J Diabetes. 2013;37(Suppl 1):S45-S55.

7. Westman EC, Feinman RD, Mavropoulos JC, et al. Low-carbohydrate nutrition and metabolism. Am J Clin Nutr. 2007;86(2):276-284.

8. Masino SA, Rho JM. Mechanisms of ketogenic diet action. Jasper's Basic Mechanisms of the Epilepsies [Internet]. 4th ed; 2012. Available from: https://www.ncbi.nlm.nih.gov/books/NBK98219/. Accessed September 21, 2018.

9. Tay J, Luscombe-Marsh ND, Thompson $\mathrm{CH}$, et al. Comparison of low- and high-carbohydrate diets for type 2 diabetes management: a randomized trial. Am J Clin Nutr. 2015;102(4):780-790.

10. Meng Y, Bai H, Wang S, Li Z, Wang Q, Chen L. Efficacy of low carbohydrate diet for type 2 diabetes mellitus management: a systematic review and meta-analysis of randomized controlled trials. Diabetes Res Clin Pract. 2017;131:124-131.

11. Hallberg SJ, McKenzie AL, Williams PT, et al. Effectiveness and safety of a novel care model for the management of type 2 diabetes at 1 year: an open-label, non-randomized, controlled study. Diabetes Ther. 2018;387:10027.

12. Wells AS, Read NW, Laugharne JD, Ahluwalia NS. Alterations in mood after changing to a low-fat diet. Br J Nutr. 1998;79(1):23.

13. Gibson AA, Seimon RV, Lee CM, et al. Do ketogenic diets really suppress appetite? A systematic review and meta-analysis. Obes Rev. 2015;16(1):64-76.

14. Sainsbury E, Kizirian NV, Partridge SR, Gill T, Colagiuri S, Gibson AA. Effect of dietary carbohydrate restriction on glycemic control in adults with diabetes: a systematic review and meta-analysis. Diabetes Res Clin Pract. 2018;139:239-252.

15. Davies MJ, D’Alessio DA, Fradkin J, et al. Management of hyperglycemia in type 2 diabetes, 2018. A consensus report by the American diabetes Association (ADA) and the European Association for the Study of Diabetes (EASD). Diabetes Care. 2018;41(12):2669-2701.

\section{Publish your work in this journal}

Diabetes, Metabolic Syndrome and Obesity: Targets and Therapy is an international, peer-reviewed open-access journal committed to the rapid publication of the latest laboratory and clinical findings in the fields of diabetes, metabolic syndrome and obesity research Original research, review, case reports, hypothesis formation, expert opinion and commentaries are all considered for publication. The manuscript management system is completely online and includes a very quick and fair peer-review system, which is all easy to use. Visit http://www.dovepress.com/testimonials.php to read real quotes from published authors.

Submit your manuscript here: https://www.dovepress.com/diabetes-metabolic-syndrome-and-obesity-targets-and-therapy-journal 